\title{
Growth and nutritional efficiency of acacia seedlings in response to phosphate fertilization
}

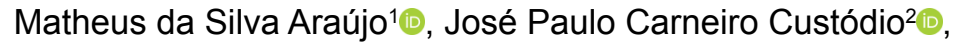 \\ Brena Ficher Augusto dos Santos ${ }^{\circledR} \odot$, Adilson Pelá ${ }^{\circledR}$, Ademilson Coneglian²

\footnotetext{
1 Universidade de São Paulo, Escola Superior de Agricultura "Luiz de Queiroz ", Piracicaba-SP, Brasil. E-mail: araujomatheus@usp.br

2 Universidade Estadual de Goiás, Ipameri-GO, Brasil.E-mail: josepaulocarneiro@outlook.com; brena_ficher@hotmail.com; adilson.pela@ueg.br; coneglian@ueg.br
}

ABSTRACT: Acacia mangium Willd cultivation is a viable option to meet the growing demand for wood in the forest market. However, there is little information related to its nutritional requirements in the seedling growth phase. The objective of this study was to evaluate the growth and nutritional efficiency of acacia seedlings in response to phosphate fertilization. The experimental design was completely randomized with five treatments, and with five replications each. The treatments consisted of five phosphorus $(\mathrm{P})$ doses: $0,50,100,150$ and $200 \mathrm{mg} \mathrm{dm}^{-3}$, and triple superphosphate $\left(46 \% \mathrm{P}_{2} \mathrm{O}_{5}\right)$ was used as the mineral source. The plant height, stem diameter, leaf number, shoot, root and total dry matter, $\mathrm{P}$ content in leaves, stem and roots, and $\mathrm{P}$ efficiency of uptake, translocation and use were subsequently evaluated 120 days post-transplant. The rate of $150 \mathrm{mg} \mathrm{dm}^{-3}$ of $P$ showed the best growth and efficiency results for $P$ use. The increases observed in acacia seedlings due to the increase in $P$ rates show the importance of adequate phosphate nutrition in the development of this species. Thus, $150 \mathrm{mg} \mathrm{dm}^{-3}$ of $\mathrm{P}$ is the recommended rate for Acacia mangium seedling cultivation.

Key words: forest nutrition; macronutrient; phosphorus

\section{Crescimento e eficiência nutricional de mudas de acácia em resposta à adubação fosfatada}

RESUMO: O cultivo de Acacia mangium Willd é uma opção viável para suprir a crescente demanda de madeiras no mercado florestal. No entanto, existem poucas informações relacionadas às suas exigências nutricionais em fase de crescimento de mudas. Objetivou-se avaliar o crescimento e a eficiência nutricional de mudas de acácia em resposta à adubação fosfatada. $O$ delineamento experimental utilizado foi inteiramente casualizado, com cinco tratamentos, com cinco repetições cada. Os tratamentos foram constituídos de cinco doses de fósforo $(P): 0,50,100,150$ e $200 \mathrm{mg} \mathrm{dm}^{-3}$, sendo a fonte mineral utilizada 0 superfosfato triplo $\left(46 \%\right.$ de $\mathrm{P}_{2} \mathrm{O}_{5}$ ). Após 120 dias do transplantio, foram avaliadas a altura da planta, diâmetro do coleto, número de folhas, matérias secas da parte aérea, raiz e total, conteúdos de $P$ nas folhas, caule e raízes, e eficiências de absorção, translocação e uso. A dose de $150 \mathrm{mg} \mathrm{dm}^{-3}$ de $\mathrm{P}$ apresentou os melhores resultados de crescimento e de eficiência de uso de P. Os incrementos observados nas mudas de acácia em razão do aumento das doses de P evidenciam a importância da adequada nutrição fosfatada no desenvolvimento desta espécie. Assim, recomenda-se a dose $150 \mathrm{mg} \mathrm{dm}_{-3}$ de P para o cultivo de mudas de Acacia mangium.

Palavras-chave: nutrição florestal; macronutriente; fósforo 


\section{Introduction}

The Brazilian forest sector is in growing demand for raw forest materials, especially planted forests, and Brazil currently has about 7.8 million hectares of planted area (Ibá, 2018). However, these plantations are not sufficient to supply the demand, which makes it extremely important to develop practices and studies to increase the productive potential of forest species (Ibá, 2018).

In this scenario, the cultivation of Acacia mangium Willd is an option to meet the growing demand for wood and may positively contribute to developing the Brazilian forest sector (Lombardi, 2013). This species has high adaptability to Brazilian edaphoclimatic conditions, fast growth, good biomass production, and above all is capable of symbiotic association with atmospheric nitrogen-fixing bacteria (Duarte et al., 2011).

The species is native to the rainforests of northeastern Australia, New Guinea and Indonesia, belongs to the Acacia genus, Leguminoseae family (Krisnawati et al., 2011). A. mangium Willd has great potential for use, being widely implemented in recovering degraded areas, in wood production for coal, energy, cellulose, wood panels and for ornamental purposes, as well as being used as windbreakers in agroforestry systems.

The areas intended for cultivation are usually soils with low fertility, and few soil management practices are performed in most cases, thus making it impossible to express their productive potential. Although the species presents good adaptability in soils with low nutrient availability (Pardos et al., 2005), it is necessary to apply fertilizers and correctives in order to increase the productivity (Schumacher et al., 2013).

Nutrient maintenance at adequate levels for plant development is achieved through mineral or organic fertilization, an essential practice to achieve the desired growth (Bernardino \& Garcia, 2009). The issue becomes even more important when it comes to crops in Cerrado soils which have low fertility and high acidity (Tavares et al., 2016). Therefore, the application of correctives and fertilizers in adequate quantities for the crop requirements is fundamental for the crops' efficiency (Vieira et al., 2014).

Plant growth depends on the availability of macronutrients $(\mathrm{N}, \mathrm{P}, \mathrm{K}, \mathrm{Ca}, \mathrm{Mg}$, and $\mathrm{S})$ and micronutrients $(\mathrm{B}, \mathrm{Cl}, \mathrm{Cu}, \mathrm{Fe}, \mathrm{Mn}$, $\mathrm{Mo}, \mathrm{Ni}$, and $\mathrm{Zn}$ ), among other factors (Faquin, 2005). Of these, phosphorus $(P)$ is one of the most required nutrients by forest species (Schumacher et al., 2003). In addition, P participates in vital metabolic processes for plant development such as energy transfer, nucleic acid and glucose synthesis, respiration, membrane synthesis and stability, enzyme activation and deactivation (Taiz \& Zeiger, 2013).

There are still few studies related to the nutritional demand of $P$ in seedling production and its importance for forest species in Cerrado soils. However, some studies show the importance of $P$ in the initial development of plants, as observed by Cardoso et al. (2015), who assessed the initial development of mahogany (Swietenia macrophylla King.), verifying the species' requirement for adequate doses of $P$ close to $41.6 \mathrm{mg} \mathrm{dm}^{-3}$. In turn, Vasconcelos et al. (2017) found the requirement of 240 $\mathrm{mg} \mathrm{dm} \mathrm{m}^{-3} \mathrm{P}$ for African mahogany (Khaya senegalensis A. Juss), as well as Moro et al. (2014) who obtained the required dose of $140 \mathrm{mg} \mathrm{dm}^{-3}$ of $\mathrm{P}$ for Pinus taeda.

Due to the importance of $P$ for plant growth, it is necessary to carry out specific studies on phosphate fertilization in the seedling growth of forest species such as Acacia mangium Willd in order to obtain the appropriate dose and requirement of this nutrient. Thus, the objective of this study was to evaluate the growth and nutritional efficiency of acacia seedlings in response to phosphate fertilization in a greenhouse.

\section{Materials and Methods}

\section{Study area}

The experiment was conducted in a greenhouse in an experimental area of Goiás State University, Campus Ipameri (geographic coordinates 17043'19" latitude S and 4809'35" longitude $\mathrm{W}$ and an altitude of $764 \mathrm{~m}$ ). The greenhouse characteristics are: $3.5 \mathrm{~m}$ in height, $30.0 \mathrm{~m}$ in length, $7.0 \mathrm{~m}$ in width, closed at the sides with $50 \%$ black shade and cover with transparent plastic of 150 microns. The temperature inside the greenhouse during the experimental period ranged from $18{ }^{\circ} \mathrm{C}$ (minimum) to $30{ }^{\circ} \mathrm{C}$ (maximum), with an average of $23^{\circ} \mathrm{C}$.

\section{Experimental design and treatments}

The experimental design was completely randomized with five treatments and five replications each, totaling 25 experimental units. The treatments consisted of five doses of $\mathrm{P}: 0,50,100,150$ and $200 \mathrm{mg} \mathrm{dm}^{-3}$, with triple superphosphate being the implemented fertilization source $\left(46 \%\right.$ of $\left.\mathrm{P}_{2} \mathrm{O}_{5}\right)$.

\section{Seedling production}

The species used was Acacia mangium Will, with its seedlings being produced from seeds from the municipality of Ipameri. Seed dormancy was broken by immersion in hot water at $100{ }^{\circ} \mathrm{C}$ for one minute to favor germination (Dutra et al., 2013). Then the seeds were sown in $53 \mathrm{~cm}^{3}$ tubes filled with commercial Carolina Soil ${ }^{\circledR}$ substrate $[\mathrm{pH}$ in water $=5.53$; organic matter $=350 \mathrm{~g} \mathrm{~kg}^{-1} ;$ total nitrogen $=1.1 \mathrm{~g} \mathrm{~kg}^{-1} ; \mathrm{Ca}^{2+}=0.7$ $\mathrm{cmol}_{\mathrm{c}} \mathrm{dm}^{-3} ; \mathrm{Mg}^{2+}=5.18 \mathrm{cmol} \mathrm{dm}^{-3} ; \mathrm{K}^{+}=7.6 \times 10^{-4} \mathrm{cmol}_{\mathrm{c}} \mathrm{dm}^{-3}$; available $P\left(\right.$ Mehlich $\left.^{-1}\right)=0.06 \mathrm{mg} \mathrm{dm}^{-3}$ ], where they remained until the transplantation date (60 days after sowing). The plants were not fertilized during this period.

\section{Soil, container and nutrient application}

The soil used was a dystrophic Latossolo VermelhoAmarelo (Embrapa, 2018), collected in the subsurface layer (0.2-0.4 m). The soil was passed through a $4 \mathrm{~mm}$ mesh sieve after collection, and homogenized for physicochemical characterization (Table 1).

Due to the physicochemical analysis of the collected soil, dolomitic limestone (PRNT $=92 \%$ ) was applied to the soil before beginning the experiment, aiming to increase the base 
Table 1. Physicochemical characteristics of a Latossolo Vermelho-Amarelo used in the experiment.

\begin{tabular}{|c|c|c|c|c|c|c|c|c|c|}
\hline $\begin{array}{c}\mathrm{pH} \\
\left(\mathrm{CaCl}_{2}\right)\end{array}$ & $\begin{array}{l}\text { Available P } \\
\left(\mathrm{mg} \mathrm{dm}^{-3}\right)\end{array}$ & $\begin{array}{c}\text { P }_{\text {REM }} \\
\left(\mathrm{mg} \mathrm{L}^{-1}\right)\end{array}$ & \multicolumn{5}{|c|}{$\left(\mathrm{cmol}_{\mathrm{c}} \mathrm{dm}^{-3}\right)$} & $\begin{array}{c}\text { SOM } \\
\left(\mathrm{g} \mathrm{dm}^{-3}\right)\end{array}$ & $\begin{array}{c}v \\
(\%)\end{array}$ \\
\hline 5.4 & 0.8 & 11.1 & 0.04 & 0.2 & 0.1 & 1.8 & 2.14 & 7.0 & 16.09 \\
\hline B & $\mathrm{Cu}$ & $\mathrm{Fe}$ & $\mathrm{Mn}$ & $\mathrm{Zn}$ & Sand & Silt & Clay & \multirow{2}{*}{\multicolumn{2}{|c|}{$\begin{array}{c}\text { Bulk density } \\
\left(\mathrm{g} \mathrm{cm}^{-3}\right)\end{array}$}} \\
\hline \multicolumn{5}{|c|}{$\left(\mathrm{mg} \mathrm{dm}^{-3}\right)$} & \multicolumn{3}{|c|}{$\left(\mathrm{g} \mathrm{kg}^{-1}\right)$} & & \\
\hline 0.28 & 0.3 & 34 & 10.1 & 0.3 & 610.0 & 80.0 & 310.0 & \multicolumn{2}{|c|}{1.21} \\
\hline
\end{tabular}

Extractors used: $\mathrm{P}$ and $\mathrm{K}=$ Mehlich $^{-1} ; \mathrm{Ca}^{2+}, \mathrm{Mg}^{2+}$ and $\mathrm{Al}^{3+}=1 \mathrm{~mol} / \mathrm{L} \mathrm{KCl} ; \mathrm{H}+\mathrm{Al}=0.5 \mathrm{~mol} / \mathrm{L}$ calcium acetate at $\mathrm{pH}$ 7.0. $\mathrm{B}=$ saturation extract in hot water; $\mathrm{Cu}$, Fe; $\mathrm{Mn}$ and $\mathrm{Mn}=\mathrm{DTPA} /$ $\mathrm{CaCl}_{2}$ (CAT). $\mathrm{P}_{\mathrm{REM}}=$ remaining phosphorus (Alvarez et al., 2000). SOM = soil organic matter (Walkley \& Black, 1934). V = base saturation. $\mathrm{H}+\mathrm{Al}=$ potential acidity. $\mathrm{CEC}=$ cation exchange capacity.

saturation (V) to $60 \%$. The soil was kept moist at $60 \%$ of the soil water retention capacity $(17 \mathrm{kPa})$ during the 40 -day period to favor the limestone reaction.

The samples were placed in $5 \mathrm{dm}^{3}$ black polyethylene pots at the end of the soil incubation period, which received the following P doses: 0, 50, 100, 150 and $200 \mathrm{mg} \mathrm{dm}^{-3}$. The triple superphosphate doses $\left(46 \% \mathrm{P}_{2} \mathrm{O}_{5}\right)$ were applied by incorporation and homogenization into the soil.

In addition, $150 \mathrm{mg} \mathrm{dm}^{-3} \mathrm{~N}$ and $150 \mathrm{mg} \mathrm{dm}^{-3} \mathrm{~K}$ in the form of urea and potassium chloride, respectively, were also added. Moreover, the following micronutrients were applied: $B(0.5$ $\left.\mathrm{mg} \mathrm{dm}{ }^{-3}\right), \mathrm{Mn}\left(1.5 \mathrm{mg} \mathrm{dm}^{-3}\right), \mathrm{Zn}\left(0.5 \mathrm{mg} \mathrm{dm}^{-3}\right), \mathrm{Cu}\left(0.5 \mathrm{mg} \mathrm{dm}^{-3}\right)$ $\mathrm{mg} \mathrm{dm}^{-3}$ ) and Mo $\left(0.1 \mathrm{mg} \mathrm{dm}^{-3}\right)$, having boric acid, manganese chloride, zinc chloride, copper sulfate and ammonium molybdate as sources, respectively. Nutrients were individually applied in each pot via nutrient solution, divided into 4 applications with an interval of 30 days each, with the first dose applied 60 days after sowing. The nutrient doses were adapted according to the work of Araújo et al. (2017).

The seedlings were transplanted to the pots at 60 days after sowing. Soil moisture was maintained throughout the experimental period at approximately $60 \%$ of the maximum soil water retention capacity. The volume of evapotranspirated water was replaced daily by weighing the vessels. The positions of the pots with the plants were randomly changed every seven days in all treatments in aiming toward homogenization and randomization of uncontrolled factors.

\section{Phytotechnical characteristics evaluated}

The following growth characteristics were evaluated 120 days after transplantation: plant height $(H)$, stem diameter (SD) and number of leaves per plant (NL). Then the plants were separated into leaves, stem and roots to determine dry matter. The plant parts were then washed with distilled water and then placed in a forced air oven for 72 hours at $70{ }^{\circ} \mathrm{C}$. After drying, they were weighed in analytical scale to determine shoot dry matter (SDM = shoot dry matter [leaf dry matter + stem dry matter]), and root dry matter (RDM), and these values were summed to obtain total dry matter (TDM).

The plant material was subsequently milled in a Wiley type stainless steel mill with a 20 mesh sieve, and the $\mathrm{P}$, leaf and stem contents were analyzed. The molybdenum blue spectrophotometry method was used to determine $P$ levels, according to the methodology described by Miyazawa et al. (2009). The P content in the leaves (LPC), stem (SPC) and root (RPC) were then calculated using the obtained data.

\section{P nutritional efficiency}

From the plant dry matter and $\mathrm{P}$ content, the phosphorus absorption (PAE) (Swiader et al., 1994), translocation (PTE) (Li et al., 1991) and usage (PUE) efficiencies were calculated (Siddiqi \& Glass, 1981) according to Equations 1, 2 and 3.

$$
\begin{aligned}
& \operatorname{PAE}\left(\mathrm{mg} \mathrm{g}^{-1}\right)=\frac{(\mathrm{LPC}+\mathrm{SPC}+\mathrm{RPC})}{\mathrm{RDM}} \\
& \operatorname{PTE}(\%)=\frac{(\mathrm{LPC}+\mathrm{SPC})}{(\mathrm{LPC}+\mathrm{SPC}+\mathrm{RPC})} \times 100 \\
& \operatorname{PUE}\left(\mathrm{g}^{2} \mathrm{mg}^{-1}\right)=\frac{(\mathrm{SDM}+\mathrm{RDM})^{2}}{(\mathrm{LPC}+\mathrm{SPC}+\mathrm{RPC})}
\end{aligned}
$$

in which: LPC = leaf phosphorus content; $\mathrm{SPC}=$ stem phosphorus content; RPC = root phosphorus content; RDM = root dry matter; SDM = shoot dry matter (leaf dry matter + stem dry matter).

\section{Statistical analyses}

The data were subjected to analysis of variance (ANOVA) and simple regression analysis after verifying the assumptions of normality and homogeneity of residual variances of the data to evaluate the influence of $P$ doses on each variable. Statistical analyzes were conducted using the SISVAR 5.4 software program (Ferreira, 2011).

\section{Results and Discussion}

According to the results obtained in this work there was a significant effect of $P$ doses on all studied variables, except on translocation efficiency, which demonstrates the importance of $P$ in the initial growth of acacia seedlings. Visually, the $150 \mathrm{mg} \mathrm{dm}^{-3} \mathrm{P}$ dose provided the highest plant growth (Figure 1). $\mathrm{P}$ influences the development of seedlings, as it participates in plant metabolism, is part of the energy transfer process (ATP formation), the structure of various organic molecules, composing membranes and esters of carbohydrates, being fundamental for cellular and photosynthetic activities (Marschner, 2012; Taiz \& Zeiger, 2013). Thus, the availability of $P$ is essential in all acacia development phases, and its deficiency can slow down the shoot and root growth. 


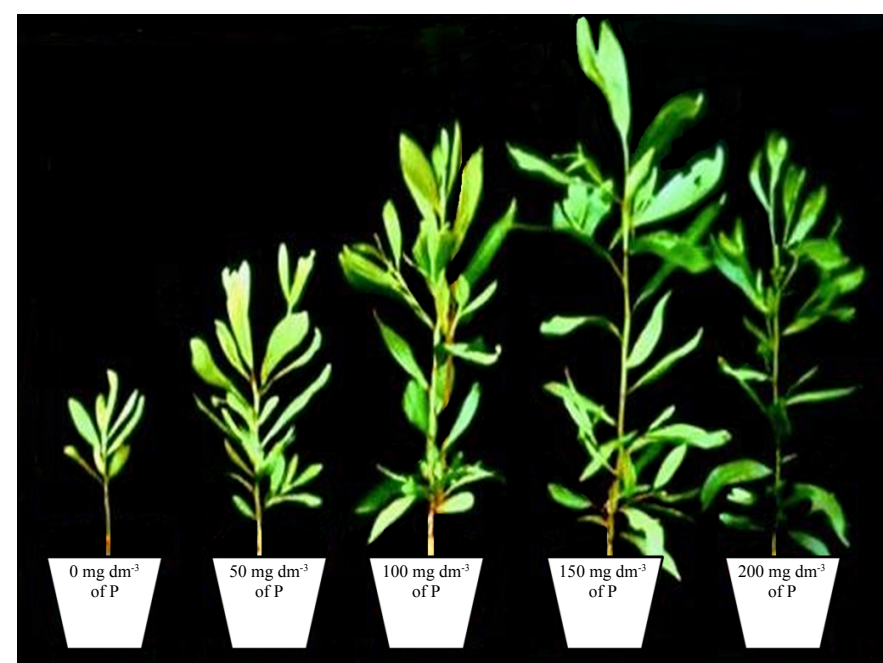

Figure 1. A. mangium Willd seedlings submitted to increasing doses of $\mathrm{P}$ at 120 days after transplantation.

The $\mathrm{H}, \mathrm{SD}$ and NL variables presented significant adjustment $(p<0.01)$ to the quadratic regression model, showing increases in response to the initial doses and decreasing in the highest $\mathrm{P}$ dose. The $\mathrm{H}$ of plants obtained with the estimated dose of $152 \mathrm{mg} \mathrm{dm}^{-3}$ of $\mathrm{P}$ was $70.3 \mathrm{~cm}$, corresponding to the maximum height reached by the plants, whose value was $143 \%$ higher than the plants grown at the $P$ dose of $0 \mathrm{mg} \mathrm{dm}^{-3}$ (Figure $2 A)$. An increase in the SD variable was observed up to the estimated dose of $127 \mathrm{mg} \mathrm{dm}^{-3}$ of $\mathrm{P}$, which corresponded to 8.4 $\mathrm{mm}$, constituting a value of $68 \%$ higher than plants submitted to the $0 \mathrm{mg} \mathrm{dm}^{-3}$ dose of $\mathrm{P}$ (Figure 2B). SD and $\mathrm{H}$ are seedling quality indicator variables which are greatly influenced by the addition of $\mathrm{P}$ (Caldeira et al., 2014). This is important because vigorous seedlings provide greater post-planting survival, increased growth and root formation (Araújo, 2018).

Phosphate fertilization was also important for leaf production. The highest NL was obtained at the estimated dose of $147 \mathrm{mg} \mathrm{dm}^{-3}$, corresponding to 58 leaves per plant ${ }^{-1}$ (Figure $2 \mathrm{C}$ ). There was a $544 \%$ reduction in NL in the absence of $P\left(0 \mathrm{mg} \mathrm{dm}^{-3}\right)$ in relation to the estimated maximum yield. Freiberger et al. (2014) stated that plants with $P$ deficiency present reduced leaf number and reduced leaf area, which corroborates the results found in the present work.

Similar results to those obtained in this study were observed by Leite et al. (2014), who found a significant increase for $\mathrm{H}, \mathrm{SD}$ and $\mathrm{NL}$ due to the increase in $\mathrm{P}$ doses in mulungu (Erythrina velutina Willd) seedlings up to $200 \mathrm{mg} \mathrm{dm}$. ${ }^{3}$. In Eucalyptus benthamii and Eucalyptus dunnii seedlings, Dias et al. (2015) also observed a positive response of the analyzed variables (dry matter production and accumulated $P)$ to different $P$ sources, showing the importance of $P$ in the development of forest species, since the plants showed a positive response independent of the source applied. In Cassia grandis L. seedlings, Freitas et al. (2017) found that phosphate fertilization at a dose of $600 \mathrm{mg} \mathrm{dm}^{-3}$ positively influenced seedling growth and quality.

When analyzing plant biomass, a significant adjustment $(p<0.01)$ was also observed for the quadratic regression model
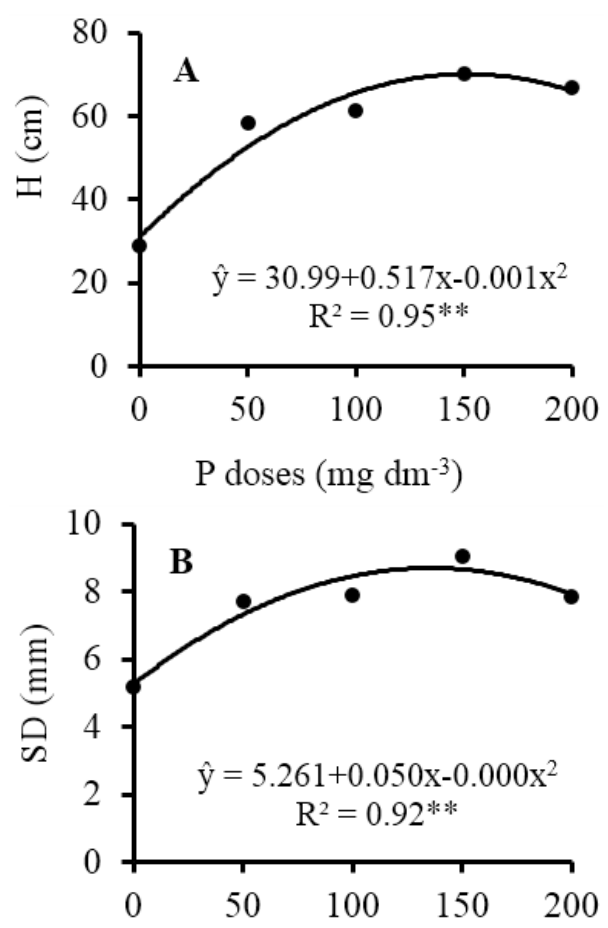

$\mathrm{P}$ doses $\left(\mathrm{mg} \mathrm{dm}^{-3}\right)$

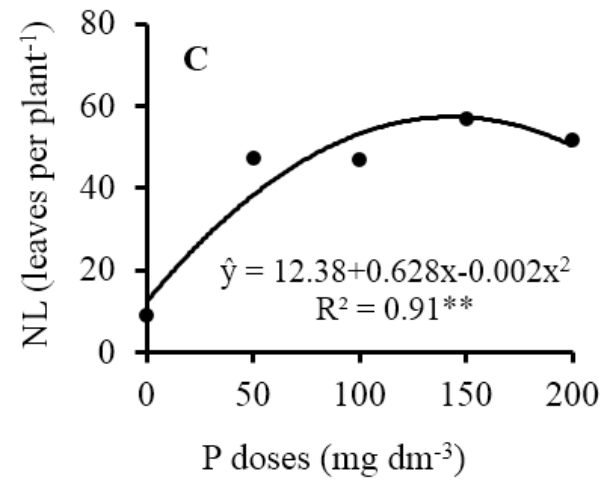

Figure 2. Equations adjusted for plant height $(A)$, stem diameter (B), and number of leaves per plant (C) of acacia as a function of $\mathrm{P} .{ }^{*}$ and ${ }^{* *}=$ significant at 5 and $1 \%$ significance, respectively.

in the SDM, RDM and TDM variables (Figure 3). The addition of $P$ in highly weathered soils (with low available $P$ content) promotes significant increases in plant biomass (Rodrigues et al., 2014; Cabral et al., 2016), as occurred in the soil used in this work, whose initial content $P$ was low $\left(0.8 \mathrm{mg} \mathrm{dm}^{-3}\right)$ (Table 1).

SDM showed an estimated increase of 27.8 g plant $^{-1}$ when grown at the estimated $P$ dose of $136 \mathrm{mg} \mathrm{dm}^{-3}$, being 8 times higher than the control $\left(0 \mathrm{mg} \mathrm{dm}^{-3}\right.$ of $\left.\mathrm{P}\right)$. In turn, plants grown at the maximum $P$ dose $\left(200 \mathrm{mg} \mathrm{dm}^{-3}\right)$ showed a $24 \%$ reduction in relation to the maximum SDM production (Figure 3A). These results corroborate Araújo et al. (2018), who reported that high $\mathrm{P}$ doses may reduce SDM production, and therefore it is essential to ensure the adequate availability of this nutrient.

There was higher RDM production at the estimated $\mathrm{P}$ dose of $153 \mathrm{mg} \mathrm{dm}^{-3}$, corresponding to $22.4 \mathrm{~g} \mathrm{plant}^{-1}$ (Figure 3B). 


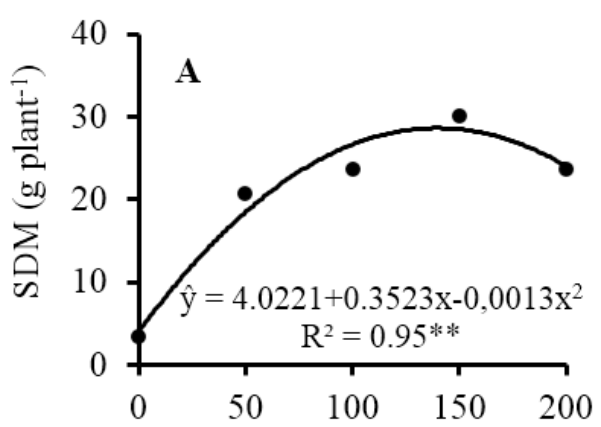

$\mathrm{P}$ doses $\left(\mathrm{mg} \mathrm{dm}^{-3}\right)$

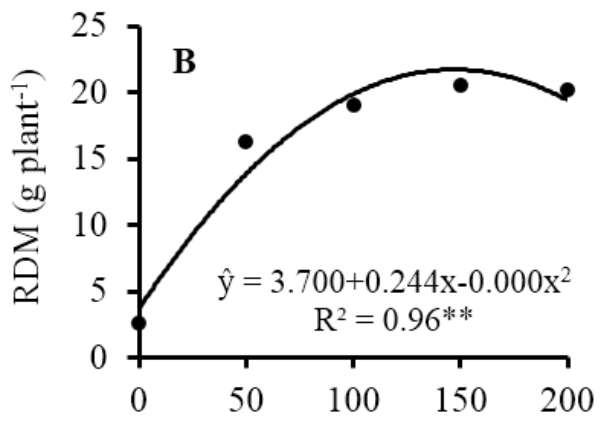

$\mathrm{P}$ doses $\left(\mathrm{mg} \mathrm{dm}^{-3}\right)$

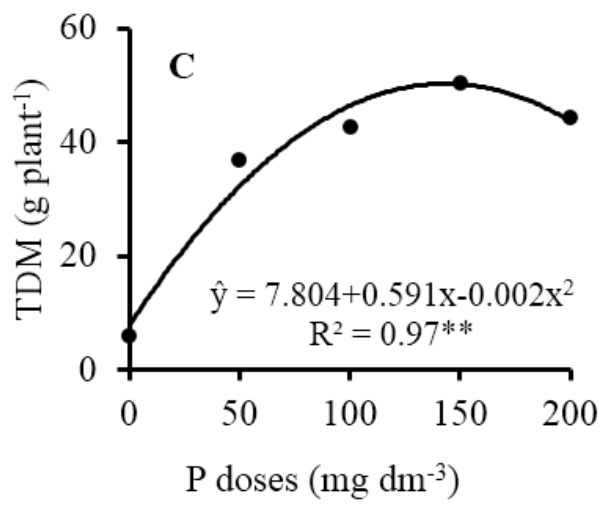

Figure 3. Equations adjusted for shoot dry matter (A), root dry matter (B), and total dry matter (C) of acacia plants as a function of $\mathrm{P} .{ }^{*}$ and ${ }^{* *}=$ significant at 5 and $1 \%$ significance, respectively.

These results are in agreement with the main function of $\mathrm{P}$ in the induction of root system growth (Corrêa et al., 2004), since $P$ is essential for its formation due to its role as energy carrier, in addition to other functions in the plant (Silva et al., 2015).

TDM yields increased to the estimated $P$ dose of $141 \mathrm{mg}$ $\mathrm{dm}^{-3}$, which resulted in a weight of $49.5 \mathrm{~g} \mathrm{plant}^{-1}$ (Figure $3 \mathrm{C}$ ). It is important to highlight that the plants reduced biomass production by applying $P$ doses above $141 \mathrm{mg} \mathrm{dm}^{-3}$. However, the absence of phosphate fertilization (dose $0 \mathrm{mg} \mathrm{dm}^{-3}$ ) promoted higher biomass losses than an excess of $P$; this behavior was also observed by Miranda et al. (2016).

The LPC, SPC, and RPC variables presented significant adjustment to the linear regression model, which showed the highest values by applying the maximum $P$ dose $\left(200 \mathrm{mg} \mathrm{dm}^{-3}\right)$ (Figure 4).
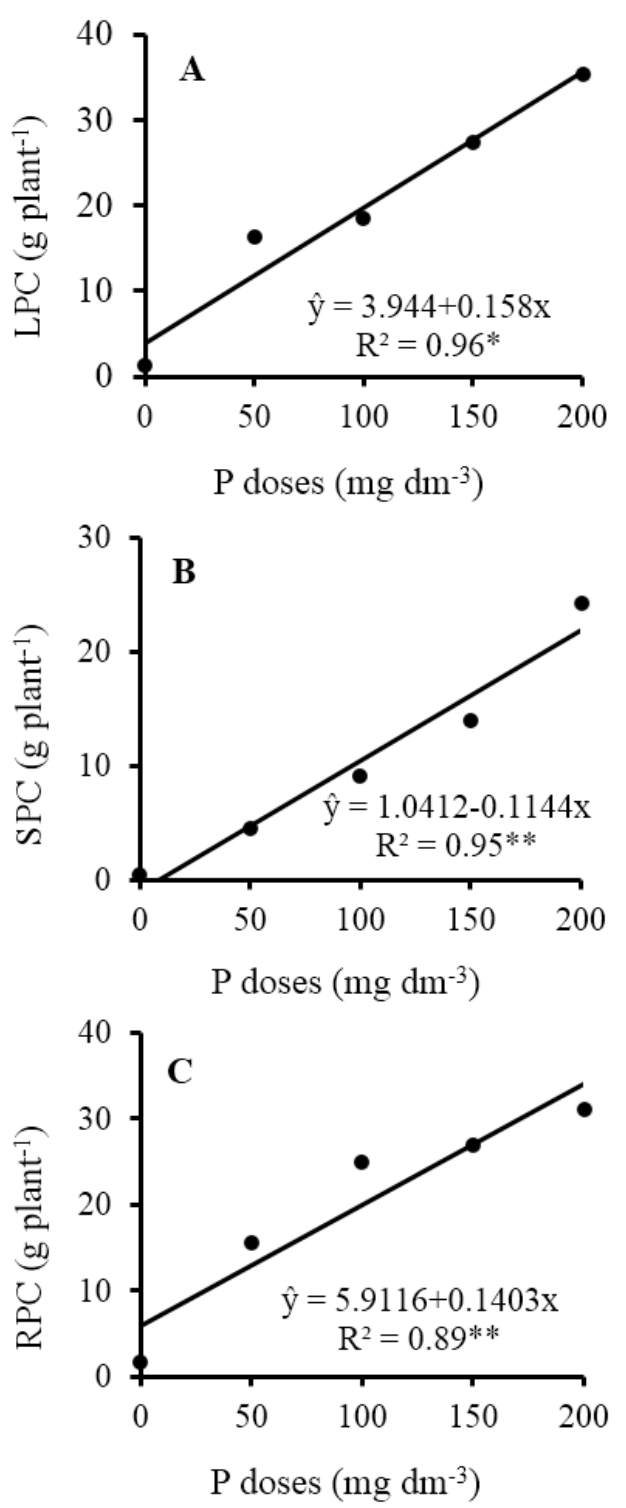

Figure 4. Regressions adjusted for $P$ content in leaves (A), stem (B) and root (C) of acacia plants as a function of P. * and $*^{* *}=$ significant at 5 and $1 \%$ significance, respectively.

Although the maximum $P$ dose $\left(200 \mathrm{mg} \mathrm{dm}^{-3}\right)$ provided the highest $P$ content values in the plant, it was the $P$ dose of 150 $\mathrm{mg} \mathrm{dm}{ }^{-3}$ which resulted in the highest biomass production. Therefore, the plants had a "luxury intake" at the maximum $P$ dose, resulting in higher nutrient levels which usually do not result in increases in dry matter yield (Taiz \& Zeiger, 2013). Although this "luxury consumption" of P occurs in the early stages of seedling development, this available P reserve will contribute to meeting plant needs in future field conditions (Gonçalves et al., 2000).

Santos et al. (2008) observed an increase of $\mathrm{P}$ content in mahogany (Swietenia macrophylla King) seedlings grown in dystrophic Yellow Latosol under greenhouse conditions as a function of increasing $P$ rates in the soil, showing a linear response in $\mathrm{P}$ content up to a dose of $800 \mathrm{mg} \mathrm{dm}^{-3}$. In guapuruvu plants (Schizolobium parahyba (Vell.) S.F.Blake), Araújo et al. (2018) also observed that leaf P concentrations 
were positively influenced by increasing $P$ doses, showing increasing linear behavior as a function of applied doses.

The plant LPC obtained at the P dose of $200 \mathrm{mg} \mathrm{dm}^{-3}$ was $35.5 \mathrm{~g} \mathrm{plant}^{-1}$, being 35 times higher than that found $(4.1 \mathrm{~g}$ plant $^{-1}$ ) for the lowest $P$ dose $\left(0 \mathrm{mg} \mathrm{dm}^{-3}\right)$ (Figure $\left.4 \mathrm{~A}\right)$. The higher $P$ dose $\left(200 \mathrm{mg} \mathrm{dm}^{-3}\right.$ ) provided a 24 -fold increase in SPC and a 15-fold increase in plant RPC when compared to the lowest dose ( $0 \mathrm{mg} \mathrm{dm}^{-3}$ ) (Figures $4 \mathrm{~B}$ and $\mathrm{C}$ ).

When analyzing the nutritional efficiency of the acacia seedlings, a significant effect $(p<0.01)$ was observed for PAE and PUE as a function of increasing $P$ doses, adjusting to the linear and quadratic regression model, respectively (Figure $5 \mathrm{~A}$ and $\mathrm{B}$ ). However, there was no significant adjustment of regression models as a function of $\mathrm{P}$ doses for the $\mathrm{PTE}$ variable (Figure 5B).

Regarding translocation efficiency, which is characterized as the process of transferring a nutrient from one organ or absorption region to another (Faquin, 2005), it was verified
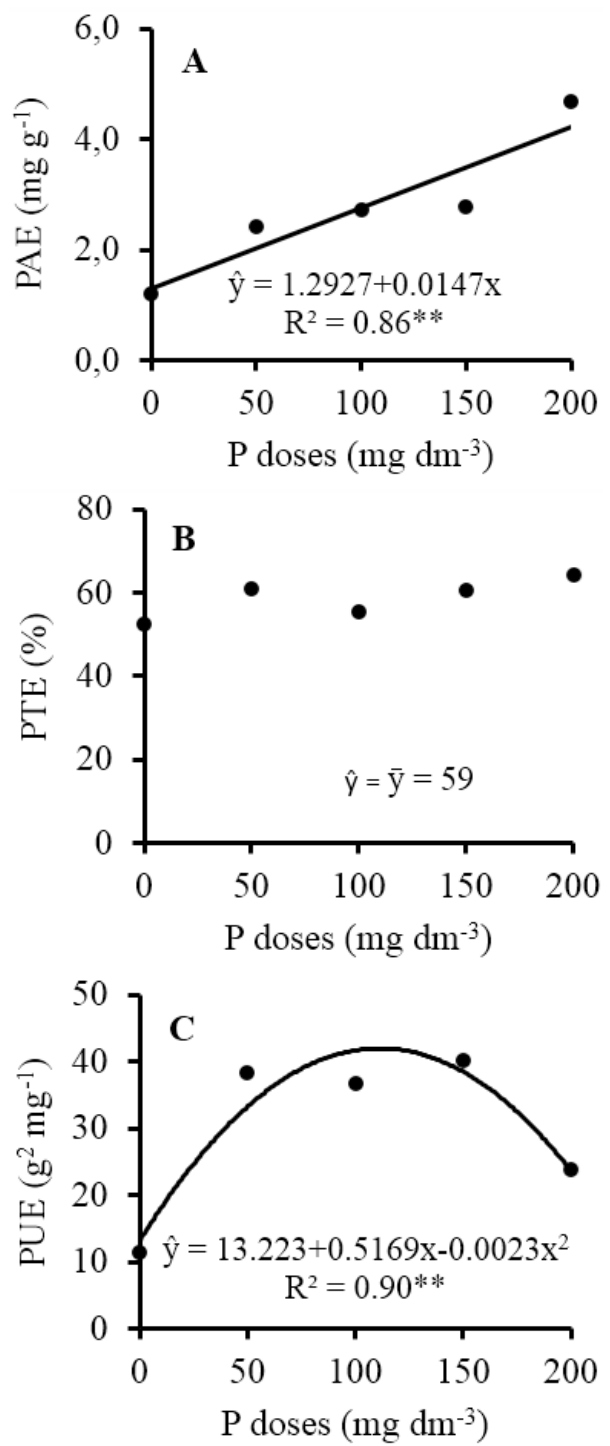

Figure 5. Adjusted equations for $P(A)$ absorption, $P(B)$ translocation and $P(C)$ usage efficiencies of acacia plants as a function of P. $*$ and ${ }^{* *}=$ significant doses at 5 and $1 \%$ of significance, respectively. that they showed similar behavior regarding nutrient translocation, although the acacia seedlings were subjected to different $P$ concentrations in the soil. Thus, the plants had proportionally the same PTE under excess $P$ conditions (200 $\mathrm{mg} \mathrm{dm}^{-3}$ ) and $\mathrm{P}$ deficiency (0 $\mathrm{mg} \mathrm{dm}^{-3}$ ) (Figure 5B).

Acacia seedlings showed higher PAE $\left(4.7 \mathrm{mg} \mathrm{g}^{-1}\right)$ when grown at the maximum $P$ dose $\left(200 \mathrm{mg} \mathrm{dm}^{-3}\right.$ ) (Figure $\left.5 \mathrm{~A}\right)$. This value was $291 \%$ higher than plants grown in the absence of phosphate fertilization ( $0 \mathrm{mg} \mathrm{dm}^{-3}$ of $\mathrm{P}$ ). This behavior was similar to that observed in the study by Stahl et al. (2013), in which Eucalyptus dunnii obtained increasing linear gains in PAE as the P supply to the soil increased.

Although seedlings absorbed more $P$ when applied at the maximum dose, the highest PUE was observed when plants were subjected to a $\mathrm{P}$ dose of $150 \mathrm{mg} \mathrm{dm}^{-3}$ (Figure $5 \mathrm{C}$ ). Therefore, the more $P$ was made available in the soil, the higher the PAE by the plants. However, the higher PAE was not accompanied by higher PUE or higher biomass production. Corroborating with the present study, the decrease of PUE with the increase in the $P$ dose has been observed in the literature, as shown by Stahl et al. (2013) and Fageria et al. (2011).

The PUE was reduced by $66 \%$ at the maximum $P$ dose (200 $\mathrm{mg} \mathrm{dm}^{-3}$ ) compared to the $150 \mathrm{mg} \mathrm{dm}^{-3}$ dose. Thus, a $\mathrm{P}$ dose application of $150 \mathrm{mg} \mathrm{dm}^{-3}$ is recommended for the studied edaphic conditions in order to avoid waste of phosphate fertilizer, because the seedlings expressed their maximum development potential in $\mathrm{H}, \mathrm{SD}, \mathrm{NL}$ and biomass production (SDM and RDM) in this condition.

Finally, it is noteworthy that acacia seedlings grown at the $P$ dose of $0 \mathrm{mg} \mathrm{dm}^{-3}$ showed visual symptoms of $P$ deficiency (Figure 1), as characterized by reduced leaf area and low growth (Ferreira, 2012). Visual deficiency symptoms are usually the last stage of several irreversible metabolic problems, and a subsequent $P$ supply to adequate levels will not compensate for the damage which has already occurred (Barroso et al., 2005). The results obtained in this work showed that adequate $P$ supply is essential in the early stages of forest seedling growth.

\section{Conclusions}

Acacia mangium Willd is responsive to phosphate fertilization during its early growth.

The approximate $P$ dose of $150 \mathrm{mg} \mathrm{dm}^{-3}$ showed the best results for growth and nutritional efficiency of $P$ use. Therefore, this $\mathrm{P}$ dose is recommended for Acacia mangium Willd seedling cultivation under similar edaphic conditions.

\section{Literature Cited}

Alvarez, V.V.H.; Novais, R.F.; Dias, L.E.; Oliveira, J.A. Determinação e uso do fósforo remanescente. Boletim Informativo Sociedade Brasileira de Ciência do Solo, v. 25, n.1, p.27-32, 2000. 
Araújo, M.S. Desenvolvimento inicial e nutrição de mudas de mognoafricano transplantadas em viveiro em resposta à adubação nitrogenada e fosfatada. Brasília: Universidade de Brasília, 2018. 49p. Dissertação Mestrado. https://repositorio.unb.br/ handle/10482/32834. 22 Jun. 2019.

Araújo, M.S.; Coneglian, A.; Hodecker, B.E.R.; Pelá, A.; Gonçalves, R.N.; Rocha, E.C. Initial growth of Brazilian Firetree (Schizolobium parahyba (Vell.) S.F.Blake) fertilized with phosphorus in RedYellow Latosol. Australian Journal Crop Science, v.12, n.7, p.11081113, 2018. https://doi.org/10.21475/ajcs.18.12.07.PNE1035.

Araújo, M.S.; Cunha, S.D.; D’abadia, K.L.; Morais, Y.C.R.; Rocha, E.C.; Barretto, V.C.M.; Coelho, G.M. Initial growth of African mahogany plants in response to zinc fertilization. African Journal of Agricultural Research, v.12, n.12, p.1022-1026, 2017. https:// doi.org/10.5897/AJAR2017.12176.

Barroso, D.G.; Figueiredo, F.A.M.M.A.; Pereira, R.C.; Mendonça, A.V.R.; Silva, L.C. Diagnóstico de deficiência de macronutrientes em mudas de teca. Revista Árvore, v.29, n.5, p.671-679, 2005. https://doi.org/10.1590/S0100-67622005000500002.

Bernardino, F.S.; Garcia, R. Sistemas silvipastoris. Pesquisa Florestal Brasileira, v.1, n.60, p.77-87, 2009. https://doi.org/10.4336/2009. pfb.60.77.

Cabral, C.E.A.; Cabral, L.S.; Silva, E.M.B.; Carvalho, K.S.C.; Kroth, B.E.; Cabral, C.H.A. Resposta da Brachiaria brizantha cv. Marandu a fertilizantes nitrogenados associados ao fosfato natural reativo. Comunicata Scientiae, v.7, n.1, p.66-72, 2016. https://doi. org/10.14295/cs.v7i1.964.

Caldeira, M.V.W.; Favalessa, M.; Gonçalves, E.O.; Delarmelina, W.M.; Santos, F.E.V.; Viera, M. Lodo de esgoto como componente de substrato para produção de mudas de Acacia mangium Wild. Comunicata Scientiae, v.5, n.1, p.34-43, 2014. https://www. comunicatascientiae.com.br/comunicata/article/view/309/231. 02. Ago. 2019.

Cardoso, A.A.S.; Santos, J.Z.L.; Tucci, C.A.F.; Farias, E.P.; Moura, R.P.M. Influência da acidez e do teor de fósforo do solo no crescimento inicial do mogno. Pesquisa Florestal Brasileira, v.35, n.81, p.1-10, 2015. https://doi.org/10.4336/2015.pfb.35.81.667.

Corrêa,J.L.; Mauad, M.; Roselem, C.A. Fósforonosoloe desenvolvimento de soja, influenciados pela adubação fosfatada e cobertura vegetal. Pesquisa Agropecuária Brasileira, v.39, p.1.231-1.237, 2004. https://doi.org/10.1590/S0100-204X2004001200010.

Dias, L.P.R.; Gatiboni, L.C.; Brunetto, G.; Simonete, M.A.; Bicaratto, B. Eficiência relativa de fosfatos naturais na adubação de plantio de Mudas de Eucalyptus dunnii maiden e Eucalyptus benthamii maiden et cambage em solo sem e com calagem. Ciência Florestal, v.25, n.1, p. 37-48, 2015. https://doi.org/10.1590/1980509820152505037.

Duarte, R.F.; Sampaio, R.A.; Brandão Junior, D.S.; Silva, H.P.; Parreiras, N.S.; Neves, J.G. Crescimento inicial de mudas de Acacia mangium cultivadas em mantas de fibra de coco contendo substrato de lodo de esgoto. Revista Árvore, v.35, n.1, p.69-76, 2011. https:// doi.org/10.1590/S0100-67622011000100008.

Dutra, T.R.; Massad, M.D.; Sarmento, M.F.Q.; Oliveira, J.C. Substratos alternativos e métodos de quebra de dormência para produção de mudas canafístula. Revista Ceres, v.60, n.1, p.72-78, 2013. https://doi.org/10.1590/S0034-737X2013000100011.
Empresa Brasileira de Pesquisa Agropecuária - Embrapa. Sistema brasileiro de classificação de solos. 5.ed. Brasília: Embrapa Solos, 2018. 201p.

Fageria, N.K.; Santos, A.B.; Heinemann, A.B. Lowland rice genotypes evaluation for phosphorus use efficiency in tropical lowland. Journal of Plant Nutrition, v.34, n.8, p.1087-1095, 2011. https:// doi.org/10.1080/01904167.2011.558153.

Faquin, V. Nutrição mineral de plantas. Lavras: UFLA; FAEPE, 2005. $183 \mathrm{p}$.

Ferreira, D.F. Sisvar: a computer statistical analysis system. Ciência e Agrotecnologia, v. 35, n.6, p.1039-1042, 2011. https://doi. org/10.1590/S1413-70542011000600001

Ferreira, M.M.M. Sintomas de deficiência de macro e micronutrientes de plantas de milho híbrido BRS 1010. Revista Agro@mbiente On-line, v.6, n.1, p.74-83, 2012. https://doi.org/10.18227/19828470ragro.v6i1.569.

Freiberger, M.B.; Guerrini, I.A.; Castoldi, G.; Pivetta, L.G. Adubação fosfatada no crescimento inicial e na nutrição de mudas de pinhão-manso. Revista Brasileira Ciência do Solo, v.38, n.1, p.232239, 2014. https://doi.org/10.1590/S0100-06832014000100023.

Freitas, E.C.S.; Paiva, H.N.; Leite, H.G.; Oliveira Neto, S.N. Crescimento e qualidade de mudas de Cassia grandis Linnaeus f. em resposta à adubação fosfatada e calagem. Ciência Florestal, v.27, n.2, p.509-519, 2017. https://doi.org/10.5902/1980509827732.

Gonçalves, J.L.M.; Santarelli, E.G.; Moraes Neto, S.P.; Manara, M.P. Produção de mudas de espécies nativas: substrato, nutrição, sombreamento e fertilização. In: Gonçalves, J.L.M.; Benedetti, V. (Eds.). Nutrição e fertilização florestal. Piracicaba: IPEF, 2000. p.309-350.

Indústria Brasileira de Árvores - Ibá. Relatório Ibá. São Paulo: Studio 113, 2018. 96p. https://iba.org/datafiles/publicacoes/relatorios/ digital-sumarioexecutivo-2018.pdf. 28 Jul. 2019.

Krisnawati, H.; Kallio, M.; Kanninen, M. Acacia mangium Willd: ecology, silviculture and productivity. Bogor: Center for International Forestry Research, 2011. 15p. https://doi. org/10.17528/cifor/003392.

Leite, T.S.; Freitas, R.M.O.; Dombroski, J.L.D.; Leite, M.S.; Rodrigues, M.R.O. Crescimento e partição da biomassa de mudas de mulungu sob adubação fosfatada e inoculação micorrízica. Pesquisa Florestal Brasileira, v.34, n.80, p. 407-415, 2014. https:// doi.org/10.4336/2014.pfb.34.80.642.

Li, B.; Mckeand, S.E.; Allen, H.L. Genetic variation in nitrogen use efficiency of oblolly pine seedlings. Forest Science, v.37, n.2, p.613626, 1991. https://doi.org/10.1093/forestscience/37.2.613.

Lombardi, L.R. Qualidade da madeira de eucalipto e Acacia mangium consorciadas para produção de polpa kraft branqueada. Viçosa: Universidade Federal de Viçosa, 2013. 115p. Dissertação Mestrado. http://locus.ufv.br/handle/123456789/3150. 24 Jun. 2019.

Marschner, P. Mineral nutrition of higher plants. 3.ed. London: Academic Press, 2012. 655p.

Miranda, E.M.; Silva, E.M.R.; Saggin Júnior, O.J. Inoculação micorrízica e adubação fosfatada na produção de mudas de Amendoim Forrageiro. Revista Ciência Agronômica, v.47, n.2, p.240-246, 2016. https://doi.org/10.4321/S0004-05922011000400034. 
Miyazawa, M.; Pavan, M. A.; Muraoka, T.; Carmo, C. A. F. S. do; Melo, W. J. de. Análise química de tecido vegetal. In: Silva, F.C. da. (Org.). Manual de análises químicas de solo, plantas e fertilizantes. 2.ed. Brasília, DF: Embrapa Informação Tecnológica; Rio de Janeiro: Embrapa Solos, 2009. p. 190-233.

Moro, L.; Gatiboni, L.C.; Simonete, M.A.; Cassol, P.C.; Chaves, D.M. Resposta de Pinus taeda com diferentes idades à adubação NPK no Planalto Sul Catarinense. Revista Brasileira de Ciência do Solo, v.38, n.4, p.1181-1891, 2014. https://doi.org/10.1590/S010006832014000400014.

Pardos, M.; Royo, A.; Pardos, J.A. Growth, nutrient, water relations, and gas exchange in a holm oak plantation in response to irrigation and fertilization. New Forests, v. 30, n. 1, p. 75-94, 2005. https://doi.org/10.1007/s11056-004-2553-x.

Rodrigues, D.S.; Camargo, M.S.; Nomura, E.S.; Garcia, V.A.; Correa, J.N.; Vidal, T.C. M. Influência da adubação com nitrogênio e fósforo na produção de Jambu, Acmella oleracea (L) R.K. Jansen. Revista Brasileira de Plantas Medicinais, v.16, n.1, p.71-76, 2014. https://doi.org/10.1590/S151605722014000100010.

Santos; J.Z.L.; Resende, A.V.; Furtini Neto; A.E.; Corte; E.F. Crescimento, acúmulo de fósforo e frações fosfatadas em mudas de sete espécies arbóreas nativas. Revista Árvore, v.32, n.5, p.799-807, 2008. https://doi.org/10.1590/S0100-67622008000500003.

Schumacher, M.V.; Ceconi, D.E.; Santana, C.A. Influência de diferentes doses de fósforo no crescimento de plantas de Peltophorum dubium (Sprengel) Taubert. Boletim Pesquisa Florestal, v.1, n.47, p.99-114, 2003. https://doi.org/10.1590/ S0100-67622004000100019.

Schumacher, M.V.; Viera, M.; Londero.; Calil, F.N.; Lopes, V.G.; Witschoreck, R. Crescimento da acácia-negra em resposta a aplicação de nitrogênio, fósforo e potássio. Cerne, v.19, n.1, p.51-58, 2013. https://doi.org/10.1590/s010477602013000100007
Siddiqi, M.Y.; Glass, A.D.M. Utilization index: a modified approach to the estimation and comparison of nutriente utilization efficiency in plants. Journal Plant Nutrition, v.4, n.3, p. 289-302, 1981. https://doi.org/10.1080/01904168109362919.

Silva, J.T.A.; Simão, F.R.; Alves, J.J. Desenvolvimento vegetativo e produção do pinhão-manso em resposta à adubação fosfatada. Revista Ceres, v.62, n.3, p.319-322, 2015. https://doi. org/10.1590/0034-737X201562030012.

Stahl, J.; Ernani, P.R.; Gatiboni, L.C.; Chaves, D.M.; Neves, C.U. Produção de massa seca e eficiência nutricional de clones de Eucalyptus dunnii e Eucalyptus benthamii em função da adição de doses de fósforo ao solo. Ciência Florestal, v. 23, n. 2, p. 287295, 2013. https://doi.org/10.5902/198050989275.

Swiader, J.M.; Chyan, Y.; Freiji, F.G. Genotypic differences in nitrate uptake and utilization efficiency in pumpkin hybrids. Journal Plant Nutrition, v.17, n.10, p.1687-1699, 1994. https://doi. org/10.1080/01904169409364840.

Taiz, L.; Zeiger, E. Fisiologia Vegetal. 6. ed. Porto Alegre: Artmed, 2013. 643p.

Tavares, S.L.R.; Franco, A.A.; Silva, E.M.R. Resposta de Acacia mangium Willd a inoculações com rizóbio e micorriza em diferentes níveis de fósforo em solo de restinga degradado. Holos, v.7, n.32, p.242257, 2016. https://doi.org/10.15628/holos.2016.3932.

Vasconcelos, R.T.; Valeri, S.V.; Cruz, M.C.P.; Barbosa, J.C.; Barretto, V.C.M. Fertilização fosfatada na implantação de Khaya senegalensis A. Juss. Scientia Forestalis, v.45, n.116, p.1-10, 2017. https://doi.org/10.18671/scifor.v45n116.05.

Vieira, C.R.; Weber, O.L.S.; Scaramuzza, J.F. Omissão de macronutrientes no desenvolvimento de mudas de mogno africano. Ecologia e Nutrição Florestal, v.2, n.3, p.72-83, 2014. https://doi.org/10.5902/2316980X16042.

Walkley, A.J.; Black, I.A. Estimation of soil organic carbon by the chromic acid titration method. Soil Science. v.37, n.1, p.29-38, 1934. https://doi.org/10.1097/00010694-193401000-00003. 